\title{
Fuzzy Consensus Qualitative Risk Analysis as a framework for the evaluation of risk events in real estate development projects
}

\author{
A. M. Aboushady ${ }^{1} \&$ S. A. R. El-Sawy ${ }^{2}$ \\ ${ }^{1}$ Structural Engineering Department, Faculty of Engineering, \\ Cairo University, Egypt \\ ${ }^{2}$ Middle Eastern Studies Department, Girls' College, Saudi Arabia
}

\begin{abstract}
This paper presents a Fuzzy Consensus Qualitative Risk Analysis framework to identify and prioritize risks encountered in real estate projects, which is applied to developing countries. The framework incorporates the consensus and quality of experts in the process of evaluating risk events and is composed of (1) a Fuzzy Expert System (FES)to determine qualification of experts;(2) Fuzzy Similarity Aggregation Algorithms to aggregate experts' opinions; and (3) a threedimensional prioritization approach to rank the risks, qualitatively. Risks are identified through a literature review and interviews with experts who rank the risks in terms of their probability of occurrence, impact and level of detection; each is described using five linguistic terms that are defined by membership functions (MFs) on a 5-point rating scale. The FES determines an importance weight factor for each expert, based on a set of predetermined qualification attributes. Experts' opinions are aggregated in a linguistic framework, based on the proximity of their opinions on the scale to ensure that their aggregated decision is a result of common agreement. The importance weight factor is combined with the consensus weight factor of each expert in the aggregation process using a scalar modifier and the Euclidean Distance Measure Function is used to determine the linguistic criticality of every risk event. A threedimensional prioritization approach applies a set of ranking rules to every risk that enables experts to rank and visualize the priority of the risks in a three-dimensional space. The framework contributes to the Real estate industry by solving a major problem for project teams in developing countries to


qualitatively evaluate risks in a fully supported linguistic framework, using fuzzy logic, which addresses the vagueness and imprecision that exist in the decision-making process.

Keywords: fuzzy sets, Fuzzy Expert System, consensus-based models, risk management.

\section{Introduction}

Risk management is an essential process in planning and developing real estate projects, which have a great impact on the construction industry. The essentiality of risk management is greater in an industry that is characterized by high levels of uncertain, such as the case of building construction. Moreover, the real estate industry plays an important role in flourishing and developing the economy of developing countries. The Indian building construction sector contributes to $6 \%$ of GDP in 2011 (Sahni [1]). The Indian building construction market grows annually with $14 \%$. Unlikely, there is no adequate research that tackles real estate risks, especially in Egypt. Thus, this there is a demand to develop this framework to assess Real estate risks in developing countries and specifically in Egypt in order to avoid the imprecision and vagueness inherited in risk analysis.

\section{Literature review}

Risk may have many interpretations and its definition can vary from one situation to another (Markowski and Mannan [2]). Many authors have studied risk management from different perspectives. Some researchers have tackled the issue of qualitative risk analysis to prioritize risk events from different perspectives. Al-Daoor [3] studied risk assessment and management of building construction projects in Gaza Strip. Algarnas [4] studied residential construction projects' risks in Saudi Arabia. Finally, Harak [5] studied risk management of BOT projects in Egypt. All the above researchers did not suggest or provide a methodology for determining experts' qualifications participated in the process of determining risk events in order to ensure that experts are qualified to perform such tasks. According to Herrera and Herrera-Viedma [6], "those individuals (experts or decision-makers) are called on to express their opinions on a predetermined set of alternatives in order to select the best one(s)". Most often, real estate project teams have difficulty in evaluating risks encountered in their projects, while real estate construction firms depend on expert judgment in assessing these risk factors (Zabaal [7]). According to Elbarkouky and Fayek [8], the two main issues that may affect the decision-making process are "extracting meaningful data from a group of experts, and combining the experts, subject opinions by resolving disagreements." This is the reason why there is a need to develop a framework to aggregate experts' opinions in prioritizing risks that can motivate expert judgment and deal with its relative vagueness and imprecision, linguistically. The framework should be also capable of assessing the quality of experts in the decision-making process and it has to enable experts to prioritize the risks, based on their probability of occurrence, impact and level of detection/control. 


\section{Objectives}

The main objective of this paper is to prioritize different risk events existed in real estate development projects. This framework combines the Fuzzy Expert System Model with the Fuzzy Similarity Aggregation Model, the Fuzzy Consensus Measurement Model and the Fuzzy Optimal Aggregation Model to assess risks in real estate development projects. The framework provides project teams with a useful tool that incorporates consensus of the project team members in performing risk criticality analysis of real estate project with the importance weight of each expert participated in the process of evaluating risks existed in real estate projects based on his or her qualifications.

\section{Methodology and model development}

The framework consists of two models: Fuzzy Expert System Model (FES) and Fuzzy Similarity Aggregation Model (Figure 1).

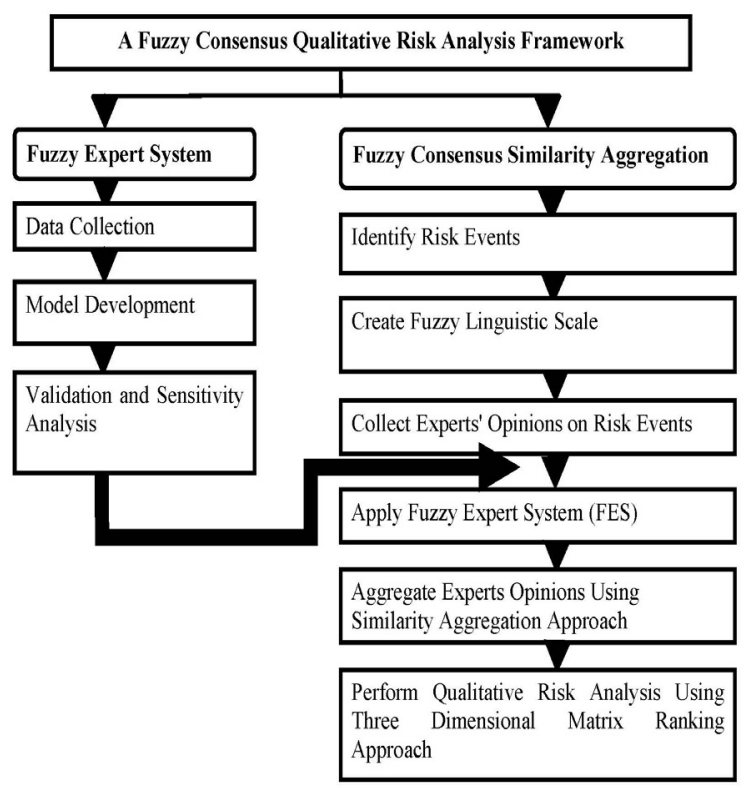

Figure 1: Model development.

\subsection{Fuzzy Expert System Model}

The Fuzzy Expert System (FES) is composed of three stages: (1) data collection and variables' development; (2) fuzzy expert system (FES) model development; and (3) validation and sensitivity analysis. Figure 2 illustrates the basic components of the FES. 


\subsubsection{Data collection and variables' development}

The first step in developing the FES model involves defining its input and output variables, developing the scales that are used to define these variables, and defining the linguistic terms describing each of these variables, using experts' judgment. Step two involves constructing the membership functions of the input, and output variables, using the modified horizontal approach with interpolation technique. Step three involves deciding on the relative influence of the input variables on the output variable, which assists on developing the rule base of the FES. In this step, data are collected from experts, using a survey-based questionnaire and a 1-5 likert scale with 1 means "very low influence" and 5 means" very high influence".

\subsubsection{Fuzzy Expert System (FES) model development}

The second stage involves the FES model development, which includes the creation of the fuzzy expert system (FES) model that is implemented using FuzzyTECH $^{\circledR}$. FuzzyTECH ${ }^{\circledR}$ software motivates the creation of the knowledge base of the fuzzy-if-then rules, automatically, based on the influence of the input variables on the output variables.

\subsubsection{Validation and sensitivity analysis}

The third stage involves the validation and sensitivity analysis to test the quality of the FES model. A case study is applied to determine the importance weight factor of a group of real estate experts in Egypt, based on their actual attributes. The output data of the model is to be validated through experts to provide an average assessment of the importance weights of the group of real estate experts. The average percentage error between the outputs of the model and the average rating of experts is calculated to validate the results of the model. Figure 3 illustrates the components of FES model.

\subsection{Fuzzy Consensus Similarity Aggregation Model}

The Fuzzy Consensus Similarity Model is composed of seven steps.

\subsubsection{Identify critical risk events}

Literature review and interviews with fifteen experts with a minimum of twenty years of experience in real estate projects in developing countries were conducted to identify critical risk events in real estate projects in developing countries. Experts have recommended that twenty seven risk events have been divided into five groups as per Table 1. The twenty seven risk events are examined in three dimensions: probability of occurrence, impact, and detection (level of control). This step resulted in categorizing twenty seven risk events in five groups and defined risk events in each group. Table (1) illustrates the risk events and their groups. 


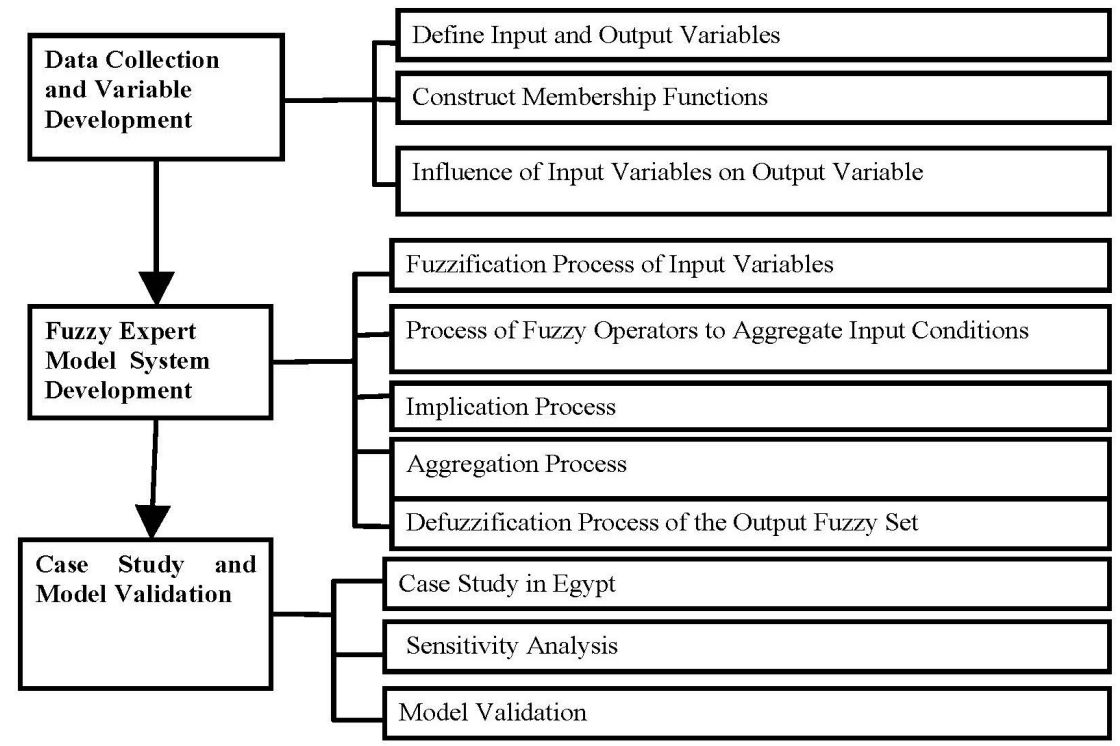

Figure 2: Components of FES Model.

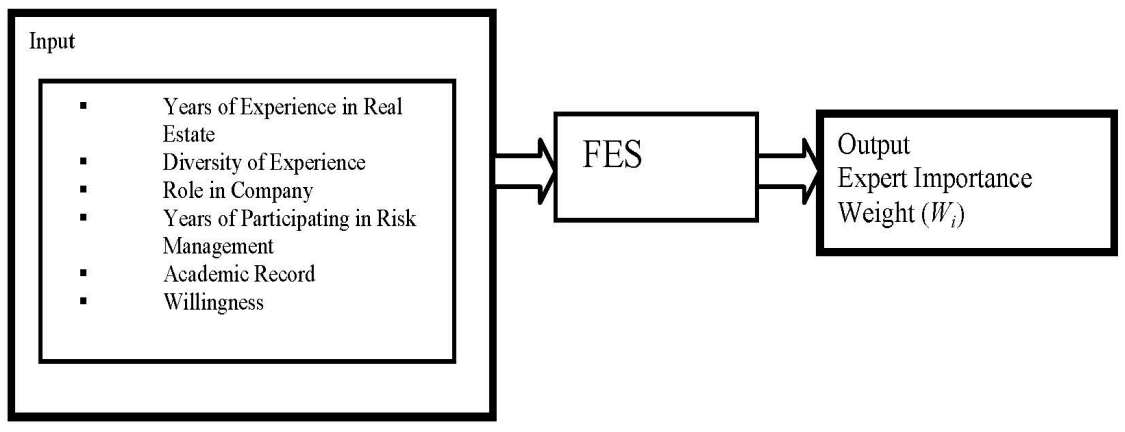

Figure 3: Applied components of FES Model.

\subsubsection{Creating a Fuzzy Linguistic Scale}

The second step is to create a fuzzy linguistic scale; through which real estate project teams can rank different risk factors affecting real estate development projects, according to the probability of occurrence, impact and level of detection, linguistically. In this stage, interviews were held with the fifteen experts and it was agreed by the experts to use a five-point Likert scale ranging from 1 to 5.1 means "very low", 2 means "low", 3 means "moderate", 4 means "high", and 5 means "very high". Furthermore, interviews were held with 
experts to decide on different elements of the scales (Table 2) for probability of occurrence, impact, and level of detection, using two-steps Delphi technique. Experts recommended the probability of occurrence and level of detection as well as the risk impact groups as per Table 3. The process of constructing the membership functions of the input and output variables determine the supports and the initial non-uniform shapes of the membership functions of the experts, using the modified horizontal approach (Elbarkouky and Fayek [8]). Figure 4 illustrates the final shape of membership function "Probability of Occurrence".

Table 1: Risk events and their groups.

\begin{tabular}{|c|c|c|c|}
\hline No. & Factors & No. & Factors \\
\hline \multicolumn{2}{|c|}{ Group (1) Design Risks } & \multicolumn{2}{|r|}{ Group (2) Financial Risks } \\
\hline 1 & $\begin{array}{l}\text { Delay of work shop } \\
\text { drawings }\end{array}$ & 6 & $\begin{array}{l}\text { Loss due to inflation (Increase in } \\
\text { the project materials, plants, } \\
\text { labors) }\end{array}$ \\
\hline 2 & $\begin{array}{l}\text { Incomplete design } \\
\text { information. }\end{array}$ & 7 & $\begin{array}{l}\text { Currency Devaluation and } \\
\text { variable rate of exchange. }\end{array}$ \\
\hline 3 & $\begin{array}{l}\text { Ambiguities, fault and } \\
\text { inconsistent } \\
\text { specifications. }\end{array}$ & 8 & $\begin{array}{l}\text { Increase in the borrowing interest } \\
\text { rate. }\end{array}$ \\
\hline 4 & $\begin{array}{l}\text { Design difficulty } \\
\text { impacting construction } \\
\text { work. }\end{array}$ & 9 & $\begin{array}{l}\text { Delay of the owner progress } \\
\text { payment to contractors. }\end{array}$ \\
\hline 5 & Increase in design fees & 10 & $\begin{array}{l}\text { Increase in the government } \\
\text { restriction to finance construction } \\
\text { companies. }\end{array}$ \\
\hline \multicolumn{2}{|c|}{ Group (3) Construction Risks } & 11 & $\begin{array}{l}\text { Decrease in the existence of } \\
\text { financially credible contractors. }\end{array}$ \\
\hline 12 & $\begin{array}{l}\text { Increase in the cost of } \\
\text { purchasing land. }\end{array}$ & \multicolumn{2}{|c|}{ Group (4) Legal and Regulation Risks } \\
\hline 13 & $\begin{array}{l}\text { Increase in the price of } \\
\text { raw materials. }\end{array}$ & 21 & Increase in the registration costs \\
\hline 14 & Increase in labor wages & 22 & $\begin{array}{l}\text { Increase in the regulation costs, } \\
\text { such as increase in the cost of } \\
\text { permits and licenses }\end{array}$ \\
\hline 15 & Poor labor productivity. & 23 & Increase in income taxation \\
\hline 16 & $\begin{array}{l}\text { Increase in the cost of } \\
\text { equipment. }\end{array}$ & 24 & Increase in customs. \\
\hline 17 & $\begin{array}{l}\text { Lack of project } \\
\text { management }\end{array}$ & 25 & $\begin{array}{l}\text { Increase in the cost of disputes } \\
\text { (Arbitration and Legislation } \\
\text { Costs) }\end{array}$ \\
\hline 18 & $\begin{array}{l}\text { Incorrect data and } \\
\text { information such as } \\
\text { surveying mistakes. }\end{array}$ & \multicolumn{2}{|c|}{ Group (5) Real Estate Risks } \\
\hline 19 & $\begin{array}{l}\text { Damage or failure risks, } \\
\text { such as cutting existing } \\
\text { electrical / telephone } \\
\text { cables }\end{array}$ & 26 & Increase in Real estate taxation \\
\hline 20 & $\begin{array}{l}\text { Shortage of skilled } \\
\text { contractors and } \\
\text { subcontractors. }\end{array}$ & 27 & Increase in the underwriting costs. \\
\hline
\end{tabular}


Table 2: Group scales representation.

\begin{tabular}{|c|c|c|c|c|c|}
\hline Input Variable & $\begin{array}{l}\text { Very } \\
\text { Low }\end{array}$ & Low & Medium & High & $\begin{array}{l}\text { Very } \\
\text { High }\end{array}$ \\
\hline $\begin{array}{l}\text { Probability of } \\
\text { Occurrence. }\end{array}$ & $1-20 \%$ & $21-40 \%$ & $41-60 \%$ & $61-80 \%$ & $81-100 \%$ \\
\hline $\begin{array}{l}\text { Impact group } 1 \\
\text { (Subjective items). }\end{array}$ & 1 & 2 & 3 & 4 & 5 \\
\hline $\begin{array}{l}\text { Impact group } 2 \\
\text { (Percentage of } \\
\text { increase). }\end{array}$ & $1-20 \%$ & $21-40 \%$ & $41-60 \%$ & $61-80 \%$ & $81-100 \%$ \\
\hline $\begin{array}{l}\text { Impact group } 3 \\
\text { (Value of Cost } \\
\text { Increase). }\end{array}$ & $\begin{array}{c}1- \\
200000 \mathrm{E} \\
\text { GP }\end{array}$ & $\begin{array}{c}201000- \\
400000 \\
\text { EGP }\end{array}$ & $\begin{array}{l}401000- \\
600000 \\
\text { EGP }\end{array}$ & $\begin{array}{l}\text { 601000- } \\
\text { 800000EGP }\end{array}$ & $\begin{array}{c}801000- \\
1000000 \\
\text { EGP }\end{array}$ \\
\hline $\begin{array}{l}\text { Impact group } 4 \\
\text { (Value of Cost } \\
\text { Increase). }\end{array}$ & $\begin{array}{c}1- \\
20000 \mathrm{EG} \\
P\end{array}$ & $\begin{array}{c}21000- \\
40000 \\
\text { EGP }\end{array}$ & $\begin{array}{c}\text { 41000- } \\
\text { 60000EGP }\end{array}$ & $\begin{array}{c}\text { 61000- } \\
\text { 80000EGP }\end{array}$ & $\begin{array}{c}81000- \\
100000 \\
\text { EGP }\end{array}$ \\
\hline Level of Detection. & $1-20 \%$ & $21-40 \%$ & $41-60 \%$ & $61-80 \%$ & $81-100 \%$ \\
\hline
\end{tabular}

Table 3: Risk events groups recommended by experts.

\begin{tabular}{|l|l|}
\hline \multicolumn{2}{|l|}{ Group One: } \\
\hline 1. & Delay of workshop drawings \\
\hline 2. & Incomplete design information. \\
\hline 3. & Ambiguities, fault and inconsistent specifications. \\
\hline 4. & Design difficulty impacting construction work. \\
\hline 5. & Delay of the owner progress payment to contractors. \\
\hline 6. & Increase in the government restriction to finance construction companies \\
\hline 7. & Decrease in the existence of financially credible contractors. \\
\hline 8. & Poor labour productivity. \\
\hline 9. & Lack of project management. \\
\hline 10. & Incorrect data and information such as surveying mistakes. \\
\hline 11. & Damage or failure risks, such as cutting existing electrical / telephone cables. \\
\hline 12. & Shortage of skilled contractors and subcontractors. \\
\hline Group Two: \\
\hline 13. & Increase in design fees \\
\hline 14. & Increase in the underwriting costs. \\
\hline 15. & Loss due to inflation (Increase in the project materials, plants, labours). \\
\hline 16. & Increase in the registration costs \\
\hline 17. & Increase in the regulation costs, such as increase in the cost of permits and licenses. \\
\hline 18. & Currency devaluation and variable rate of exchange. \\
\hline 19. & Increase in real estate taxation \\
\hline 20. & Increase in the borrowing interest rate. \\
\hline 21. & Increase in income taxation. \\
\hline 22. & Increase in customs. \\
\hline 23. & Increase in the cost of disputes (arbitration and legislation costs). \\
\hline Group Three: \\
\hline 24. & Increase in the price of raw materials. \\
\hline 25. & Increase in labour wages. \\
\hline 26. & Increase in the cost of equipment. \\
\hline Group Four: \\
\hline 27. & Increase in the cost of purchasing land \\
\hline
\end{tabular}




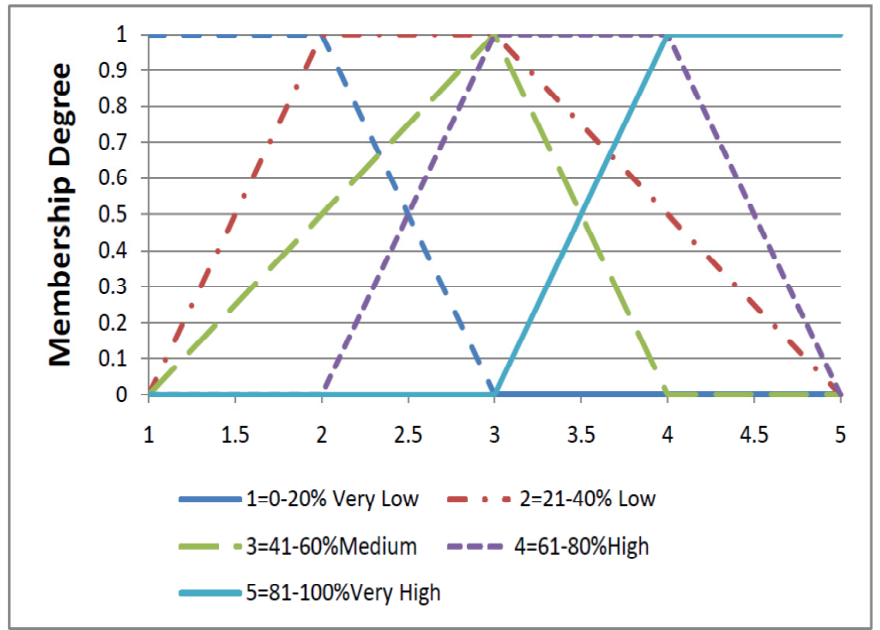

Figure 4: Final shape of the membership function "Probability of Occurrence".

\subsubsection{Collect experts' opinions on risk events}

In order to collect the opinion of experts regarding risk factors affecting real estate Development projects, a questionnaire-based survey was prepared concerning Real estate Projects in developing countries. The questionnaire is divided into two main sections. The first section contains the demographic information of experts, such as name, diversity of experience, role in company, years of participation in risk management process, years of experience in real estate projects, and his or her academic records. These experts' attributes assist in developing the Fuzzy Expert System (FES) to calculate the experts' importance weight step (4). The second section of the questionnaire was divided into three main sub-sections. The first sub-section deals with the "Probability of Occurrence" and the expert is asked the question, "what is the probability of occurrence for each risk event? Please answer the question by placing a check in the scale". The second sub-section deals with the impact of event on real estate projects. The expert is asked the question, "what is the impact (cost) for each risk event? Please answer the question by placing a check in the appropriate box". The third sub-section deals with detection (level of control). The expert was asked the question, "what is the detection (level of control) for each risk event? Please answer the question by placing a check in the appropriate box". The data collected was then analyzed using the Similarity Aggregation Model, which is explained in steps four and five.

\subsubsection{Apply Fuzzy Expert System (FES)}

The fourth step is to apply the Fuzzy Expert System (FES) to calculate an importance weight for each expert participating in the risk assessment process. Table 4 illustrates an example of the five experts' attributes and their importance weights. 
Table 4: Experts' attributes and their importance weights.

\begin{tabular}{|l|l|l|l|l|l|l|l|}
\hline Ex. & $\begin{array}{c}\text { Real } \\
\text { Estate }\end{array}$ & $\begin{array}{c}\text { Years } \\
\text { in Risk }\end{array}$ & Role & $\begin{array}{c}\text { Diversity } \\
\text { of } \\
\text { Experience }\end{array}$ & A.R. & \multicolumn{1}{|l}{ W. } & $\begin{array}{c}\text { Importance } \\
\text { Weights }\end{array}$ \\
\hline $\mathbf{1}$ & $16-20$ & $16-20$ & P.M. & V. High & Master & V. High & 0.0455 \\
\hline $\mathbf{2}$ & $1-5$ & $1-5$ & S.P.E. & V. High & Bachelor & V. High & 0.0250 \\
\hline $\mathbf{3}$ & $16-20$ & $16-20$ & P.M. & Average & Master & Average & 0.0290 \\
\hline $\mathbf{4}$ & $16-20$ & $16-20$ & P.M. & Average & Master & High & 0.0353 \\
\hline $\mathbf{5}$ & $16-20$ & $16-20$ & S.P.E. & Average & Master & High & 0.0320 \\
\hline
\end{tabular}

As listed in table 4 above the A.R. stands for academic record, W. stands for willingness to provide information, P.M. stands for project manager, and S.P.E stands for senior project engineer.

\subsubsection{Aggregate experts opinions using Fuzzy Similarity Aggregation Algorithms}

The first step is to compute the agreement degree $S\left(R_{i}, R_{j}\right)$ between every two standard fuzzy numbers, representing experts' ratings. The agreement degree is the intersection area of the MFs representing the ratings of experts divided by the bounding area, using (1).

$$
\begin{gathered}
S(R i, R j)=\int_{\underline{X}}(\min \{\mu \operatorname{Ri}(X), \mu R j(X)\}) d x \\
\int_{X}(\max \{\mu \operatorname{Ri}(X), \mu R j(X)\}) d x
\end{gathered}
$$

where, $\mu R_{i}$ and $\mu R_{j}$ equals the relevant membership degrees of every element $(X)$ of the fuzzy ratings selected by the experts on the scale. The second step is to compute the average agreement degree of experts $(A A D)$ by averaging the degrees of similarity of each expert $(i)$ with respect to other experts using (2), where $n$ is the number of experts, and $\mathrm{A}$ and $\mathrm{B}$ are the two fuzzy trapezoidal numbers selected by experts $i$ and $j$.

$$
\operatorname{AADExpert}(i)=\frac{1}{n-1} \sum_{j=1 \text { and } j \neq 1}^{n}(S(A . B))
$$

The third step is to compute the relative agreement degree (RAD) of every expert, using (3).

$$
R A D(i)=\frac{A(E i)}{\sum_{i=1}^{n} \mathrm{~A}(\mathrm{E} i)}
$$


where $A\left(E_{i}\right)$ is the average level of agreement of an expert with other experts, and it is computed by dividing the sum of his or her agreement degrees with other experts by (n-1) number of experts. The fourth step is to calculate the Consensus Degree Coefficient of every expert $\left(C D C_{(i)}\right)$, which combines the relative aggregation weight of expert $\left(R A D_{(i)}\right)$ obtained from step (2) for every expert with his/her normalized importance weight $\left(w_{i}\right)$ of experts calculated by FES, using (4).

$$
C D C(i)=\beta * W i+(1-\beta) * R A D(i)
$$

The fifth step is to determine the fuzzy number $R$, which is the sum of the multiplication of the $C D C_{i}$ of each expert by the fuzzy number $R_{i}$ that represents his or her fuzzy rating, using 5.

$$
R=\sum_{i=1}^{n}\left(C D C_{i} * R_{i}\right)
$$

The sixth step is to apply Euclidean Distance Measure to determine the final extent of risk event. step, the final linguistic terms that assess the probability of occurrence, impact, and level of detection of every risk event is determined by defining the relevant linguistic term that best matches the aggregated fuzzy number R. This is achieved through computing the Euclidean distance measure, which is proposed by Heilpern [9], to determine the final linguistic term that assesses the critical risk in those three dimensions by measuring the Euclidean distance between the quadruple $\left(r_{1}, r_{2}, r_{3}, r_{4}\right)$ of the aggregated fuzzy number $R$ and those of the standard fuzzy ratings $S_{(k)}$ on the scale, as in (6).

$$
d g(R, S)=\frac{\left(\sum_{i=1}^{n}\left|r_{i}-s_{i}\right|\right)^{1 / p}}{n}
$$

where $P$ equals 2 for the Euclidean distance measure function, $n$ equals 4 because each fuzzy number is represented by a quadruple, $r_{i}$ is the value of each element of $R$, and $S_{i}$ is the corresponding number forming the quadruple of each of the standard fuzzy ratings $S_{(k)}$ on the scale. The linguistic term that best describes the aggregated fuzzy number $(R)$ is the closest standard fuzzy rating $S_{(k)}$ to it on the scale.

\subsubsection{Qualitative Risk Analysis}

The sixth step is to apply the three dimensional ranking approach that utilizes specific linguistic ranking rules (Abdelgawad [10]) in order to produce a prioritized list of qualified risk events. Table 5 shows the fuzzy prioritization rules. Table 6 illustrates the final list of identified risk events affecting real estate development projects. 
Table 5: Fuzzy prioritization rules.

\begin{tabular}{|c|c|c|c|c|}
\hline $\begin{array}{c}\text { Rule } \\
\text { Number }\end{array}$ & $\begin{array}{c}\text { Probability } \\
\text { of } \\
\text { Occurrence }\end{array}$ & Impact & $\begin{array}{c}\text { Level of } \\
\text { Detection }\end{array}$ & $\begin{array}{c}\text { Risk } \\
\text { Criticality }\end{array}$ \\
\hline $\mathbf{1}$ & H & H & L & VH \\
\hline $\mathbf{2}$ & VH & VH & VL & VH \\
\hline $\mathbf{3}$ & VH & VH & L & VH \\
\hline $\mathbf{4}$ & H & VH & L & VH \\
\hline $\mathbf{5}$ & VH & H & VL & VH \\
\hline $\mathbf{6}$ & H & H & VL & VH \\
\hline $\mathbf{7}$ & H & M & L & H \\
\hline $\mathbf{8}$ & L & M & L & L \\
\hline $\mathbf{9}$ & H & M & H & L \\
\hline $\mathbf{1 0}$ & M & M & M & M \\
\hline $\mathbf{1 1}$ & L & L & H & VL \\
\hline $\mathbf{1 2}$ & L & L & M & L \\
\hline $\mathbf{1 3}$ & M & M & VH & L \\
\hline $\mathbf{1 4}$ & VL & VL & M & VL \\
\hline $\mathbf{1 5}$ & VL & VL & H & VL \\
\hline $\mathbf{1 6}$ & VL & VL & VH & VL \\
\hline $\mathbf{1 7}$ & L & VL & VH & VL \\
\hline $\mathbf{1 8}$ & L & L & VH & VL \\
\hline
\end{tabular}

\section{Conclusion}

In this paper, a Fuzzy Risk Management Framework was proposed to identify, and qualify risks encountered in real estate projects. The framework incorporated consensus, and quality of experts in the process of evaluating risk factors affecting real estate projects. Risks were identified through literature review and experts' interviews and were prioritized using Three-Dimensional Matrix Ranking Approach. Consensus weight factor for each expert participated in the Risk Assessment process was determined, using the Fuzzy Consensus Measurement Framework. The findings of the Fuzzy Consensus Measurement Framework in terms of highly ranked risk events will be further quantified using the Fuzzy Fault, and Event Trees Model. The framework provides an improvement over the previous risk management models by incorporating the experts' qualifications, and consensus weight factor of experts in evaluating risks in real estate projects in qualitative manner. 
Table 6: Final list of identified risk events.

\begin{tabular}{|c|c|c|c|c|c|}
\hline Risk Event & Probability & Impact & Detection & $\begin{array}{c}\text { Risk } \\
\text { Criticality }\end{array}$ & Rank \\
\hline Loss due to inflation & $\mathrm{H}$ & $\mathrm{H}$ & $\mathrm{L}$ & VH & 1 \\
\hline $\begin{array}{l}\text { Increase in the price of raw } \\
\text { materials }\end{array}$ & $\mathrm{VH}$ & VH & VL & VH & 1 \\
\hline $\begin{array}{l}\text { Increase in the cost of } \\
\text { equipment }\end{array}$ & $\mathrm{VH}$ & VH & $\mathrm{L}$ & VH & 1 \\
\hline Increase in labor wages & $\mathrm{VH}$ & $\mathrm{VH}$ & $\mathrm{VL}$ & VH & 1 \\
\hline $\begin{array}{l}\text { Currency devaluation and } \\
\text { variable rate of exchange. }\end{array}$ & $\mathrm{H}$ & $\mathrm{VH}$ & VL & VH & 1 \\
\hline $\begin{array}{l}\text { Increase in the borrowing } \\
\text { interest rate. }\end{array}$ & VH & $\mathrm{H}$ & VL & VH & 1 \\
\hline $\begin{array}{l}\text { Decrease in the existence of } \\
\text { financially credible } \\
\text { contractors. }\end{array}$ & $\mathrm{H}$ & $\mathrm{H}$ & VL & VH & 1 \\
\hline $\begin{array}{l}\text { Increase in the government } \\
\text { restriction to finance } \\
\text { construction companies. }\end{array}$ & $\mathrm{H}$ & $\mathrm{H}$ & VL & VH & 1 \\
\hline Increase in design fees & $\mathrm{H}$ & $\mathrm{M}$ & $\mathrm{L}$ & $\mathrm{H}$ & 2 \\
\hline $\begin{array}{l}\text { Shortage of skilled } \\
\text { contractors and } \\
\text { subcontractors }\end{array}$ & M & M & M & M & 3 \\
\hline Poor labor productivity & $\mathrm{L}$ & $\mathrm{M}$ & $\mathrm{L}$ & $\mathrm{L}$ & 4 \\
\hline Lack of project management & $\mathrm{H}$ & M & $\mathrm{H}$ & $\mathrm{L}$ & 4 \\
\hline Damage or failure risks & $\mathrm{L}$ & $\mathrm{L}$ & $\mathrm{M}$ & $\mathrm{L}$ & 4 \\
\hline $\begin{array}{l}\text { Increase in the cost of } \\
\text { disputes }\end{array}$ & M & M & $\mathrm{VH}$ & $\mathrm{L}$ & 4 \\
\hline $\begin{array}{l}\text { Incomplete design } \\
\text { information. }\end{array}$ & $\mathrm{L}$ & $\mathrm{L}$ & M & $\mathrm{L}$ & 4 \\
\hline $\begin{array}{l}\text { Increase in the regulation } \\
\text { costs }\end{array}$ & $\mathrm{L}$ & $\mathrm{L}$ & M & $\mathrm{L}$ & 4 \\
\hline Delay of work shop drawings & $\mathrm{L}$ & $\mathrm{L}$ & $\mathrm{H}$ & VL & 5 \\
\hline $\begin{array}{l}\text { Increase in real estate } \\
\text { taxation }\end{array}$ & $\mathrm{L}$ & $\mathrm{L}$ & $\mathrm{H}$ & VL & 5 \\
\hline $\begin{array}{l}\text { Ambiguities, fault and } \\
\text { inconsistent specifications. }\end{array}$ & $\mathrm{L}$ & $\mathrm{L}$ & $\mathrm{H}$ & VL & 5 \\
\hline $\begin{array}{l}\text { Design difficulty impacting } \\
\text { construction work }\end{array}$ & VL & VL & M & $\mathrm{VL}$ & 5 \\
\hline $\begin{array}{l}\text { Delay of the owner progress } \\
\text { payment }\end{array}$ & VL & VL & $\mathrm{H}$ & VL & 5 \\
\hline $\begin{array}{l}\text { Increase in the underwriting } \\
\text { costs }\end{array}$ & VL & VL & VH & VL & 5 \\
\hline $\begin{array}{l}\text { Increase in the cost of } \\
\text { purchasing land }\end{array}$ & $\mathrm{L}$ & $\mathrm{VL}$ & VH & VL & 5 \\
\hline $\begin{array}{l}\text { Incorrect data and } \\
\text { information such as } \\
\text { surveying mistakes }\end{array}$ & $\mathrm{L}$ & $\mathrm{L}$ & $\mathrm{H}$ & VL & 5 \\
\hline $\begin{array}{l}\text { Increase in the registration } \\
\text { costs }\end{array}$ & $\mathrm{VL}$ & VL & $\mathrm{VH}$ & $\mathrm{VL}$ & 5 \\
\hline Increase in income taxation & $\mathrm{L}$ & $\mathrm{L}$ & VH & VL & 5 \\
\hline Increase in customs & $\mathrm{L}$ & $\mathrm{L}$ & $\mathrm{H}$ & VL & 5 \\
\hline
\end{tabular}




\section{References}

[1] Sahni, S., "Real Estate Sector - The India Story Report Paper", pp. 1-9, 2012.

[2] Markowski, A. S. and Mannan, M. S. "Fuzzy risk matrix." Journal of Hazardous Materials, 159 (1), pp. 152-157, 2008.

[3] Al-Daoor, M. Z. "Risk Assessment and Management of Building Construction Projects in Gaza Strip". Master Thesis Dissertation, Faculty of Engineering, Cairo University, Giza, Egypt, 2010.

[4] Algarnas, A. M. "Residential Construction Projects Risk in Saudi Arabia", Master Thesis Dissertation, Faculty of Engineering, Cairo University, Giza, Egypt, 2007.

[5] Harak, I. A. "Risk Management of the BOT Projects in Egypt", Master Thesis Dissertation, Faculty of Engineering, Cairo University, Giza, Egypt, 2002.

[6] Herrera, F. and Herrera-Viedma, E. "Linguistic decision analysis: steps for solving decision problems under linguistic information." Fuzzy Sets and Systems, 115(1), pp. 67-82, 2000.

[7] Zabaal, N. Y. "Risk Management of Pipeline Infrastructure Projects in Egypt", Master of Science Thesis, Structural Engineering Department, Cairo University, Egypt, 2007.

[8] Elbarkouky, M. and Fayek, A. R. "Fuzzy Similarity Consensus Model for Early Alignment of Construction Project Teams on the Extent of Their Roles and Responsibilities", Journal of Construction Engineering and Management, 137(6), pp. 432-441, 2011.

[9] Heilpern, S. "Representation and application of fuzzy numbers", Fuzzy Sets, 91 (2), pp. 259-268, 1997.

[10] Abdelgawad, M. "Hybrid Decision Support System for Risk Criticality Assessment and Risk Analysis", Thesis Dissertation, Faculty of Graduate Studies and Research, Department of Civil and Environmental Engineering, University of Alberta, Edmonton, Alberta, 2011. 